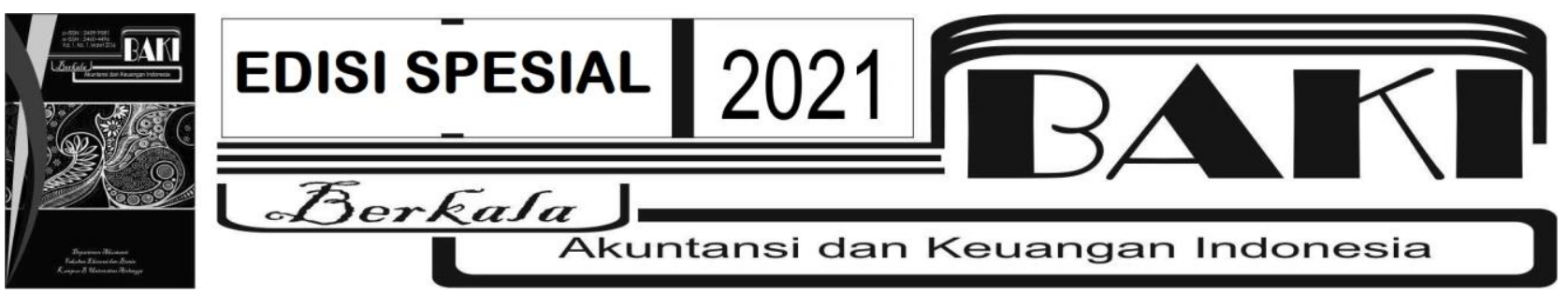

\title{
DELIVERING GAMIFICATION TO OVERCOME FINANCIAL PROBLEMS DURING A PANDEMIC
}

\section{MENYAMPAIKAN GAMIFIKASI UNTUK MENGATASI MASALAH FINANSIAL DI MASA PANDEMI}

\author{
Arief Dwi Saputra ${ }^{*}$ iD, Alfina Rahmatia ${ }^{2}$, Sri Handari Wahyuningsih ${ }^{3}$ \\ 1 Universitas Muhammadiyah Yogyakarta \\ 2Universitas Ahmad Dahlan \\ 3Universitas Muhammadiyah Yogyakarta
}

“corresponding author: arief.dwi.psc19@mail.umy.ac.id

\begin{tabular}{l} 
I N F O A R T I K E L \\
\hline Histori Artikel: \\
Tanggal Masuk $01 \mathrm{Mei} 2021$ \\
Revisi Diterima 17 Mei 2021 \\
Tanggal Diterima 15 Juli 2021 \\
Tersedia Online 31 Juli 2021
\end{tabular}

\section{Keywords:}

Gamification,

Management,

Period, MSME Business

\section{A BSTRACT}

The pandemic period causes financial management problems in the business sector that create stress. The pandemic period causes financial management problems in the business sector that create stress. This study aims to present financial gamification as a method of financial management by utilizing the game process in reducing stress. Gamification refers to changing behavior by developing Financial sinancial emotions in the game model. This research uses a qualitative study Pandemic approach. Data processing is done by collecting data through literature studies (reputable journals) and interviews. The data is managed using Nvivo plus 12 through coding similarity analysis, and a conclusion is drawn. Data collection was obtained by interviewing through a convenience sampling technique. To strengthen this research, in addition to literature studies with reputable journal sources, the interview validation process in this study was carried out by testing credibility through literature studies references. This study uses the MDA framework, namely Mechanics, Dynamics, and Aesthetics, as a game analysis method. This study explains that the application of gamification can reduce stress by creating pleasant feelings, reducing boredom, overcoming fatigue, and providing an exciting experience in managing finances. The scarcity of this pandemic problem also creates gamification by making players financially literate in financial management. In addition, the gamification element can provide an assessment of each financial management and procedural rating at the implementation stage. In addition, this study provides an update in the form of solutions in 
financial management with stages that are more systematic and can be used because they are relevant and easy to practice.

\begin{tabular}{lr}
\hline Kata Kunci: & Gamifikasi \\
Keuangan, & Pengelolaan \\
Keuangan, Masa Pandemi, \\
Bisnis UMKM
\end{tabular}

A B S TR A K

Masa pandemic menimbulkan permasalahan pengelolaan keuangan pada sektor bisnis yang menciptakan stres. Tujuan studi ini adalah untuk menyampaikan gamifikasi keuangan sebagai metode pengelolaan keuangan dengan memanfaatkan proses games dalam mengurangi stres. Gamifikasi mengacu pada perubahan perilaku dengan mengembangkan emosi pada model permainan. Penelitian ini menggunakan pendekatan studi kualitatif. Pengolahan data dilakukan dengan mengumpulkan data melalui studi pustaka (jurnal bereputasi) dan wawancara. Data tersebut dikelola menggunakan Nvivo plus 12 melalui coding similarity analysis dan ditarik suatu kesimpulan. Pengumpulan data diperoleh dengan wawancara melalui teknik convenience sampling. Untuk memperkuat penelitian ini selain studi pustaka dengan sumber jurnal yang bereputasi, proses validasi wawancara pada pada studi ini dilakukan dengan uji kredibilitas melalui referensi studi literatur. Studi ini menggunakan MDA framework, yakni Mecahnics, Dynamics, and Aesthetis sebagai metode analisa game. Hasil pada studi ini menjelaskan penerapan gamifikasi dapat mengurangi stress dengan menciptakan perasaan yang menyenangkan, mengurangi kebosanan, mengatasi kelelahan, dan memberikan pengalaman yang menarik dalam mengelola keuangan. Kelangkaan masalah pandemic ini juga menciptakan gamifikasi dengan membuat pemain melek finansial pada pengelolaan keuangan. Selain itu, elemen gamifikasi dapat memberikan penilaian pada setiap pengelolaan keuangan dan peringkat terhadap prosedural pada tahapan pelaksanaan. Di tambah lagi, studi ini memberikan pembaruan berupa solusi pada pengelolaan keuangan dengan tahapan yang lebih sistematis dan dapat digunakan karena bersifat relevan dan mudah dipraktekan.

Berkala Akuntansi dan Keuangan Indonesia p-ISSN: 2459-9581; e-ISSN 2460-4496

DOI: $10.20473 /$ baki.v6ix.26638

Open access under Creative Common Attribution-Non Commercial-Share A like 4.0 International Licence (CC-BY-NC-SA)@(1) @(

\section{Introduction}

The COVID-19 pandemic, which has been going on since the beginning of 2020, has already hit the economy. Many companies are forced to roll out because of this pandemic. As a result, many people lose their jobs and often experience financial problems due to pandemics. The number of workers affected by layoffs reached 3.05 million people. That number is expected to continue to rise to 5.23 million people (Minister of Manpower, 2020).

In addition to the news of increasingly heard layoffs, trimming salaries and benefits also occur in various companies. Moreover, there is no certainty when this pandemic ends. So is when the economy can bounce back. The situation of the COVID-19 pandemic has undeniably triggered a lot of stress and anxiety. Moreover, the necessity of social distancing makes social life a stress release. The news is an increasingly spooky economy day by day (Novi, 2020). 
Populix \& Teman Bumil (2020) survey results showed that 9 out of $10(91 \%)$ homemakers who took the survey claimed to be affected by Covid-19. A total of 643 people (60\%) experienced the biggest problems in the financial sector, $37 \%$ in the health sector related to anxiety over Covid-19, and only $3 \%$ of homemakers had problems with distance education for their children. The causes of financial difficulties are different depending on socioeconomic groups and domicile areas. Victims of pay cuts, more experienced by upper-middle-class respondents. As for the lower middle class, the average victim of layoffs and harder to find work.

Financial problems that make the community stressed. $56 \%$ of respondents admitted to being stressed with this condition, even some (25\%) relationships with a partner. Symptoms of stress include anxiety (29\%), sleeplessness (18\%), irritability (17\%), and loss of interest in doing anything. Unfortunately, no respondents tried to seek help from a professional (doctor or psychologist) and look for data or information related to addressing financial problems due to the pandemic. They tend to surrender and surrender (63\%) or ask for support from husbands (19\%). Other housewives tried to find pleasure and self-entertainment (8\%).

This study reviews the problems of offering solutions to manage financial problems because pandemics can be applied through easy and relevant tricks. Therefore, the strategy reviewed is gamification strategy, a method of learning or completing tasks by utilizing games or games. Thus, financial gamification is arguably a method of financial learning by utilizing games or games. This study aims to solve stress in financial management in the pandemic through gamification strategies.

\section{Review of Literature}

\section{1 Gamification}

The use of game models in non-game contexts has been defined as gamification (Deterding, 2011). Robson et al. (2016) defined changes in non-game behavior conditions in applying game model principles. The same as stated by Deterding (2011), but instead of motivating, this research refers to behavior change. Robson et al. (2016) analyze how the companies create a more engaging experience through a traditional approach by facilitating behavior change through customer engagement and employee engagement. These researchers assume that change is channeled through intrinsic rewards and extrinsic assistance.

Barata et al. (2017) recommend that gamification involves the user in adopting various behaviors consistent with typical commercial definitions. This definition suggests a general process in which gamification includes three elements: emotions, mechanisms, and dynamics 
(Sailer \& Homner, 2020). based on Hamari et al. (2014), gamification can be inferred on three dimensions: psychological abilities, motivation, and behavior. Dicheva \& Dichev (2017) goes one step further and argues that gamification is not only a methodology that enables behavioral change but also relates to technology.

Although the compulsory gamification segment has not been analyzed, some are most widely used or referenced, such as experience points and levels (used for ranking, feedback, and progress goals), challenges or quests (tasks with clear objectives and increasing difficulty level), Badges or rewards (which are distributed to increase motivation) and leaderboards (which stimulate competitiveness and continuous improvement) (Barata et al., 2017).

Likewise, Kevin Werbach (2012) refers to the trinity of gamification design elements, namely awards (levels) or badges, points, and leaderboards. This concept can be implemented in empirical and theoretical domains with applications in education, marketing, health care, human resources, training, environmental protection, and organizational well-being (Seaborn \& Fels, 2015). For the most part, the potential is thought to develop engagement, motivation, friendly competition, collaboration, behavior change in different contexts, including employee performance and social loyalty (Dicheva \& Dichev, 2017). Nevertheless, the specification needs to be analyzed with a multidisciplinary literature review among the various findings on gamification-based program development (Deterding, 2011).

Even though the goal-setting theory has been used to study gamification (Oettingen \&Gollwitzer, 2012), psychological theories are most often used in gamification research because they focus on psychological growth, including the need to feel competent, need to feel connected to others, and the need for autonomy (Seaborn \&Fels, 2015). The situation needed to improve the action of developing those needs (Ryan et al., 2014).

Research shows that gamification can escalate activity (Denny, 2013) and performance (Domínguez et al., 2013). However, there are not many empirical studies that mainly refer to entrepreneurship. In addition, Deterding \& Nacke (2017) assumes a lack of other research that assesses behavioral outcomes outside of what is usually assessed. To our knowledge, there is only a handful of studies exploring the effect of gamification on entrepreneurial behavior through entrepreneurship education on personal factors of entrepreneurial interest (Arief \& Alfina, 2021). Therefore, our study aims to analyze those possibilities that are relevant.

\subsection{Element of gamification}

Gamification applies design theory in games using game design elements in nongaming contexts in everyday situations, including in business. Gamification has a simple concept: redesigning routines in the office such as training and recruitment that are made in 
such a way as to be like a video game or interactive game that has the main goal to improve a more exciting work experience (Simpson \& Jenkins, 2015).

The application of game elements that can be applied in the company can be points, levels, and others. Applying these elements has the primary function of attracting and increase employee motivation (Sitorus, 2016). Gamification is also a touch of old and new implementation in the company's management, and one example is the application of the old company provides the value of employee information to direct and improve employee performance. In contrast, the new one with the company's gamification can provide employee performance information with real-time access and continuous employee performance information (Cardador et al., 2017).

Based on some theories that have been mentioned, a gamification is an approach in the form of real-time feedback from the application of game principles in managing work in an organization, thus having a positive impact on engagement and productivity of work. Gamification measures that match our research are three aspects, namely: Purpose, application of game elements, alignment of employee objectives with the company; personal motivation, motivation, rewards in the form of points, badges, levels and other incentives and performance, skills development, company feedback to employees, access to worker performance results, and employee challenge levels.

This framework is one of the most commonly used in creating games; MDA stands for Mechanics, Dynamics, and Aesthetics. Mechanics relates to the main functions of a game. Game mechanics that give the rules in the game. Some of the elements included in Mechanics are points, levels, leaderboards, and badges. The game is created, there will be an interaction between the player and the rules of the game. Dynamics is how to regulate the player's reaction to the game's rules and between the player and the other player by looking at the state of the game mind of the player. The elements included in dynamics include progression, creativity, productivity, scarcity. Aesthetics is part of the rules of how players feel when playing the game from the results of Mechanics and Dynamics interactions that can bring out emotions. Elements included in aesthetics include challenges, fellowships, discovery, expression, and sensation (Hunicke et al., 2004; Robson et al., 2015; Mora et al., 2017).

\section{Research Methodology}

This study uses a qualitative study approach. Data processing is done by collecting data through library studies (reputable journals) and interviews. Furthermore, the data is managed using Nvivo plus 12. Through coding similarity analysis, a conclusion is drawn. Nvivo analyzes qualitative data to produce more professional results (Hilal \& Alabri, 2013). To strengthen this research, in addition to the study of pustaka with reputable journal sources, proses validation of 
interviews on this study was conducted with a credibility test through reference literature studies. This research uses grounded theory based on research by Hunicke et al. (2004); Robson et al. (2015); Mora et al. (2017) on MDA Framework, a method used to analyze games by breaking them down into three main components, namely, Mechanics, Dynamics, and Aesthetics.

Data collection is also conducted by interview through convenience sampling techniques obtained from anyone encountered or by chance near researchers. This is done because of government policies related to health protocols to reduce the number transmission of covid-19. Then determine the sample number according to the sample size that will be used as the actual data source by paying attention to the characteristics of the population and its distribution to obtain a representative sample (Sholikhah, 2016). The sample of this study is MSMEs affected by the pandemic in the financial field.

There were 87 samples from various MSME business fields (online and offline businesses), consisting of 69 samples of the culinary sector, 7 samples of the fashion sector, and 11 samples of the service sector from data collection. Data collection was carried out by interviewing through the WhatsApp, Zoom, and Google meet applications. Furthermore, the results of the interviews were compiled and coded automatically using the Nvivo 12 application with text analysis techniques through word similarity. To strengthen interpretation, sentiment analysis through aspect-based sentiment analysis is used to understand and classify emotions through aspects and stages that will receive positive, neutral, or negative ratings from players.

\section{Results and Discussion}

\section{Results}

This study manages literature studies that explain the different roles in the application of gamification. Some literature explains this research refers to behavior changes by giving a pleasant feeling to the game model. Gamification deployment creates a more engaging experience through user engagement in adopting various behaviors and consistencies critical in a business context. There is a positive and significant influence of gamification on job satisfaction in reducing boredom and overcoming fatigue. Gamification elements can be applied through the MDA Framework, a method used to analyze games by breaking them down into three main components: mechanics, dynamics, and Aesthetics. In addition, gamification is not only a methodology that allows behavior change but also relates to technology. The potential application of the gamification model is considered to be able to develop emotions to reduce stress on engagement, motivation, friendly competition, collaboration, behavior change in different contexts, including activities, employee performance, and social loyalty.

Table 1. Literature studies 


\begin{tabular}{ll}
\hline Authors & Findings \\
\hline Deterding (2011) & This research refers to changes in behavior \\
Robson et al. (2016) & $\begin{array}{l}\text { Analyzed the findings of companies applying the play model by } \\
\text { creating more engaging experiences through a traditional } \\
\text { approach by facilitating behavior change through customer and } \\
\text { employee engagement. }\end{array}$
\end{tabular}

Barata et al. (2017) Recommends that gamification involves the user in adopting a variety of behaviors, consistent with typical commercial definitions

Lawande et al. (2016) The role of HR in policymaking and employee engagement is crucial in the business context.

Hunicke et al. (2004) Gamification elements can be applied through the MDA Framework, a method used to analyze games by breaking them down into three main components, Namely, Mechanics, Dynamics, and Aesthetics.

Hamari et al. (2014) The gamification model can be concluded in three dimensions, namely psychological abilities, motivation, and behavior.

Ërgle \& Ludviga

Dicheva \& Dichev (2017)

There is a positive and significant influence of gamification on job satisfaction.

Argues that gamification is not only a methodology that enables behavioral change but also about technology. The potential for the application of the gamification model is considered to develop engagement, motivation, friendly competition, collaboration, behavior change in different contexts, including employee performance and social loyalty.

Kevin Werbach (2012) Refers to the gamification design elements, namely awards (levels) or badges, challenges, points, and leaderboards.

Prasad et al. (2020) The results showed a five-dimensional scale of effectiveness of the company's gamification highlighting how employees view the company's gamification. It also shows a positive and significant relationship between employee perception of gamification and employee engagement.

Seaborn \&Fels, Gamification models can be implemented in empirical and (2015) theoretical domains with applications in education, marketing, health care, human resources, training, environmental protection, and organizational well-being.

Denny (2013) Gamification models can increase activity and performance 
\&Domínguez et al., (2013)

Source: literature studies, processed (2021)

The process conducted in this study is reviewed through literature studies which are then developed through applying financial gamification. Table 2 will explain the stages ranging from identifying financial problems, setting the scale of financial priorities, effective use of finance, classifying financial focus on controllable interests, financial management in utilizing opportunities to implement a relevant and straightforward gamification model. The stages will be reviewed through gamification elements such as mechanics who manage rules and progress, dynamics related to players' state of mind, and Aesthetics that describe player behavior. Furthermore, questions are asked regarding the application of gamification to be achieved, namely relieving stress in financial management. Applying financial gamification will offer a pleasant feeling, reduce boredom, overcome fatigue, and provide an exciting experience.

Table 2. Financial Gamification Implementation Process

\begin{tabular}{|c|c|c|c|}
\hline $\begin{array}{l}\text { Stages of } \\
\text { implementation of } \\
\text { financial gamification }\end{array}$ & $\begin{array}{l}\text { Gamification } \\
\text { Elements } \\
\text { MDA Framework }\end{array}$ & question & Goals achieved \\
\hline $\begin{array}{l}\text { Step 1: Identify } \\
\text { financial problems } \\
\text { Step 2: Scale } \\
\text { financial priorities }\end{array}$ & $\begin{array}{l}\text { - Mechanics (set } \\
\text { up the rules and } \\
\text { progression: } \\
\text { point, level, }\end{array}$ & $\begin{array}{l}\text { Will gamification } \\
\text { make progress in } \\
\text { managing the } \\
\text { rules of the game }\end{array}$ & $\begin{array}{l}\text { Relieving Stress } \\
\text { - } \\
\text { - } \\
\text { Nice feeling (V1) } \\
\text { boreduce } \\
\text { bom (V) }\end{array}$ \\
\hline $\begin{array}{l}\text { Step 3: Effective } \\
\text { financial use }\end{array}$ & $\begin{array}{l}\text { leaderboard, and } \\
\text { badge) }\end{array}$ & $\begin{array}{l}\text { Will gamification } \\
\text { describe strategic }\end{array}$ & $\begin{array}{l}\text { Overcoming } \\
\text { fatigue (V3) }\end{array}$ \\
\hline $\begin{array}{l}\text { Step 4: Classify the } \\
\text { financial focus on } \\
\text { controllable interests }\end{array}$ & $\begin{array}{l}\text { - Dynamics } \\
\text { (Players' state of } \\
\text { mind: }\end{array}$ & $\begin{array}{l}\text { behaviors and } \\
\text { actions in } \\
\text { interacting }\end{array}$ & $\begin{array}{l}\text { - Interesting } \\
\text { experience (V4) }\end{array}$ \\
\hline $\begin{array}{l}\text { Step 5: Financial } \\
\text { management in } \\
\text { taking advantage of } \\
\text { opportunities }\end{array}$ & $\begin{array}{l}\text { progression, } \\
\text { creativity, } \\
\text { productivity, } \\
\text { scarcity) }\end{array}$ & $\begin{array}{l}\text { Will gamification } \\
\text { regulate feelings } \\
\text { and provide stable } \\
\text { emotions }\end{array}$ & \\
\hline $\begin{array}{l}\text { Step 6: Implement a } \\
\text { simple and relevant } \\
\text { gamification model. }\end{array}$ & $\begin{array}{l}\text { - Aesthetics } \\
\text { (Player behavior: } \\
\text { challenges, } \\
\text { fellowship, } \\
\text { discovery, } \\
\text { expression, and }\end{array}$ & & \\
\hline
\end{tabular}


sensation)

Source: Hunicke et al., (2004); Robson et al., (2015); Mora et al., (2017), modified (2021)

Figure 1 , the process is done by looking at each stage of gamification implementation starting from stages $1-6$ with players generated through the interview process. The data was obtained after the interview process was conducted with a sample of 87 people who were affected by the pandemic. The sample consists of MSME entrepreneurs who feel stressed and have difficulty in financial management. In the review conducted, all of the informants considered the steps taken to solve the problem at hand. This can be seen from the correlation that occurs after coding with text analysis techniques through word similarity. Players feel that the steps taken have been appropriately implemented. It is starting with the identification process to the application of gamification. This explains that each stage in applying gamification to players can be used in implementing the MSME business because it is considered very relevant and easy to do. Thus, each stage passed can overcome the laziness of financial management with gamification.

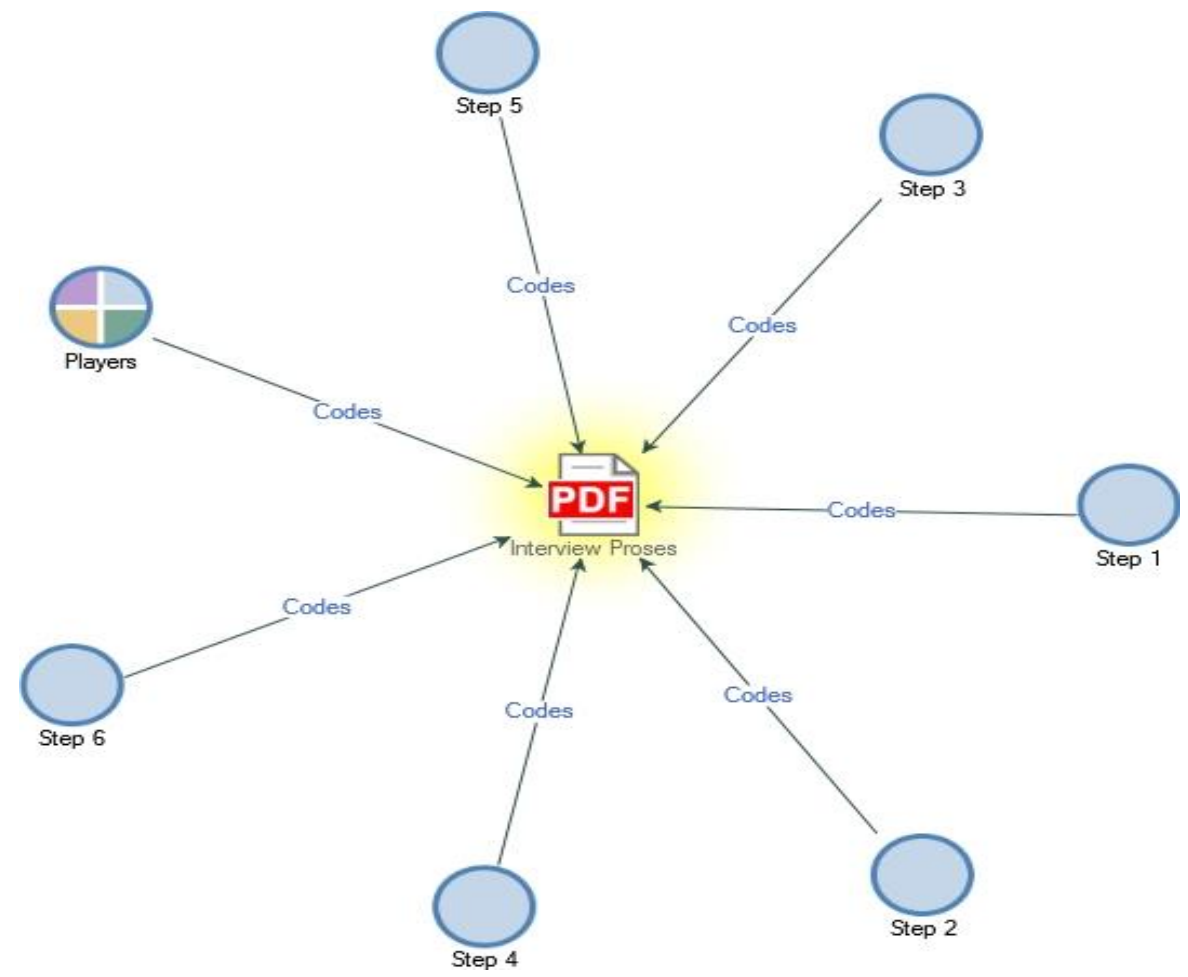

Figure 1

Support gamification stage

Source: Nvivo analysis, processed (2021)

Figure 2 will explain the application of gamification through gamification on the problem that occurs with a review of the goals to be achieved in overcoming the stressful state of the player during the pandemic. The data was obtained through the interview results, then drawn conclusions, and youth were processed using Nvivo 12 to review the total percentage of $100 \%$. 
The goal consists of feeling pleasant (V1), reducing boredom (V2), overcoming fatigue (V3), and providing an exciting experience (V4). This is achieved by encouraging the application of gamification that provides the concept of games in financial management. Thus, it brings out a feeling of willingness to play while working.

In the review conducted (figure 2), the mechanics' element played a more dominant role in V4 and V1 with $33 \%$ and $28 \%$ percentages. In dynamics elements, the role is more dominantly shown in V1 and V4 through percentages of $31 \%$ and $27 \%$. While the aesthetic element there is the same role in V1 \&V2 with a percentage of $28 \%$. In V3, on the application of mechanics elements (14\%), dynamics (22\%), and aesthetics (19\%), there is a relatively stable movement of roles. However, in the overall review, the application of gamification to achieve V1, V2, V3, and V4 gained a percentage of $98 \%$. This shows that every element of gamification, mechanics, dynamics, and aesthetics can overcome the stress of managing finances during the pandemic by presenting a pleasant feeling (V1), reducing boredom (V2), overcoming fatigue (V3), and providing an interesting experience (V4).

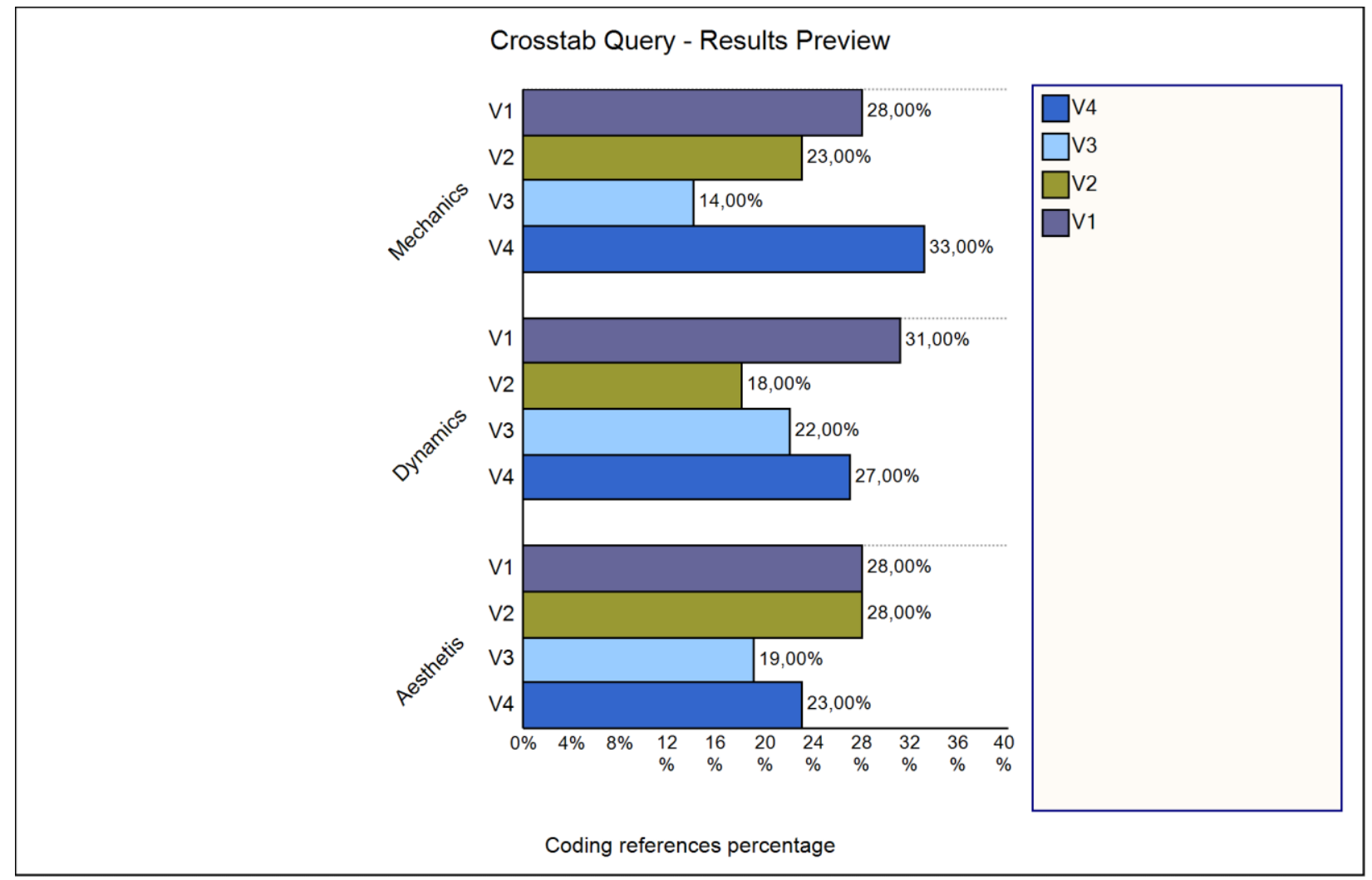

Figure 2

Gamification Element Implementation

Source: Nvivo analysis, processed (2021)

The overall review (figure 3 ) describes the stages of applying financial gamification, elements of gamification, and the objectives of the study to be achieved. In the three reviews, a similarity coding process will show the role and support between each other. It appears that 
gamification elements such as mechanics, dynamics, and aesthetics can synergize with each other by providing roles and support to the goals to be achieved, namely V1, V2, V3, and V4. Interpretation is strengthened by showing sentiment analysis through aspect-based sentiment analysis on the grouping of emotions in aspects and stages that receive positive assessments from players. This explains that the application of each review obtains support by being mutually correlated and forming mutually reinforcing relationships between each other. In addition, the role assigned by each review provides proof that gamification can be a strategy. Thus, it can face the pandemic by overcoming financial management problems that cause stress by creating pleasant feelings, reducing boredom, overcoming fatigue, and providing an interesting experience on the application of gamification.

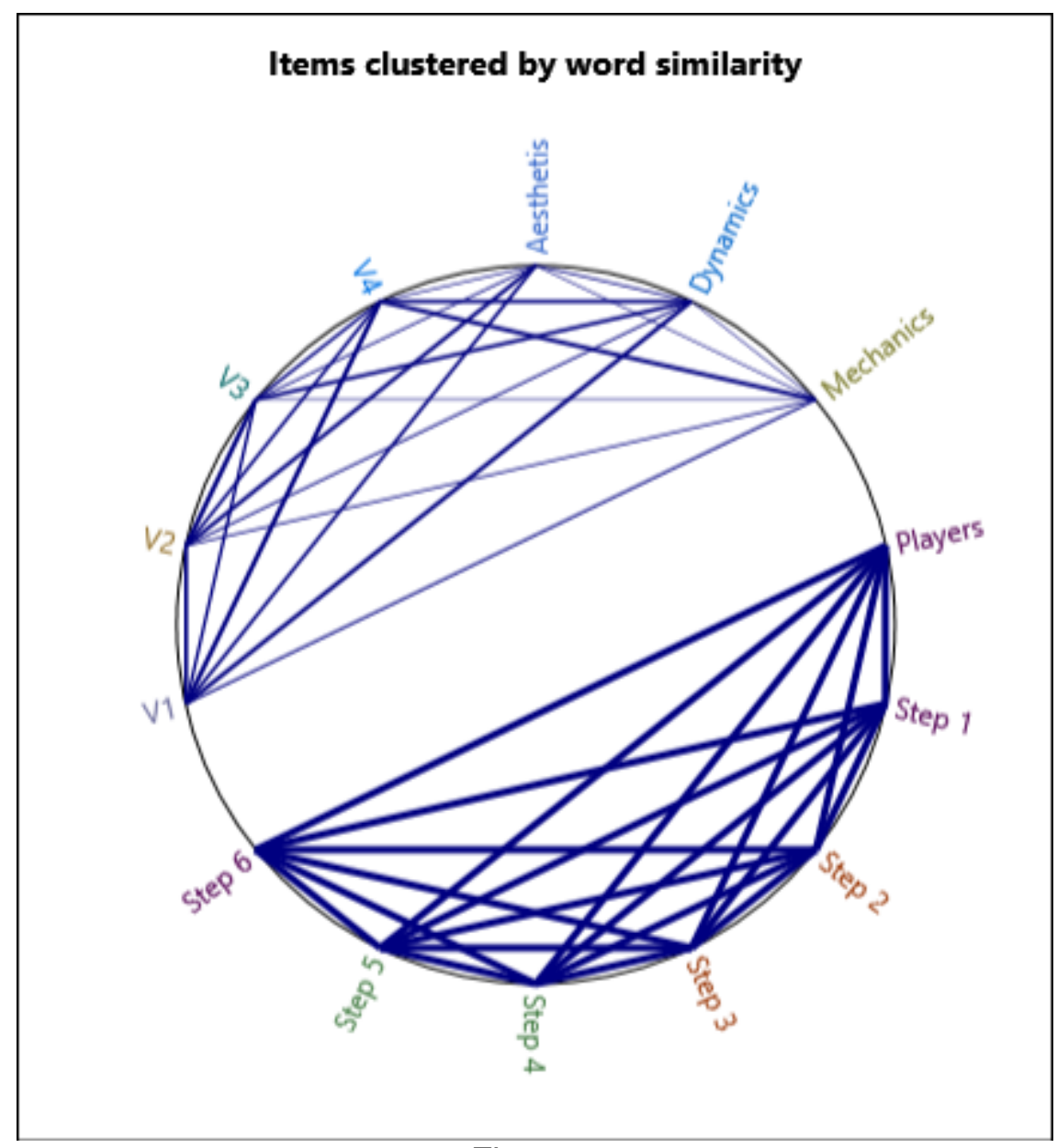

Figure 3

Relationship between reviews

Source: Nvivo Analysis, Processed (2021)

\section{Discussion}

Gamification is defined as learning or completing tasks by utilizing games or games in a non-gaming context. This research explains that gamification can be applied to the field of finance. Financial management is done game-based that offers behavior changes such as the 
invention made by Deterding (2011). This study raised the problem of financial management that causes stress due to the pandemic period. Thus, the update to this study offers financial gamification as a method of financial management by utilizing games.

This study describes the stages developed by the identification process on financial problems that occur. In the discovery of the identification stage, there are financial problems due to passive financial management. This is due to excessive feelings of stress or anxiety triggered by something frustrating or disturbing. The situation of the COVID-19 pandemic has undeniably triggered a lot of stress and anxiety. This is what the study's findings explain through the study's pleasant taste with gamification strategies. This supports previous research by Dicheva \& Dichev (2017), which explained that gamification could develop pleasant motivations.

This study also supports research by Saputra \& Rahmatia (2021) on gamification to create creativity and innovation. Gamification also reduces boredom in its application. This happens because of the dynamics process's effect on the player's state of mind in describing strategic behaviors and actions in interacting. The scarcity of pandemic problems also creates gamification by making players financially literate in financial management. Thus, the resulting income will create productivity.

Furthermore, Robson et al. (2016) analyzed the findings on the application of game models by creating more engaging experiences through traditional approaches by facilitating behavior changes through player engagement. This study also explains and supports previous research that gamification provides a more interesting experience in financial management. This is reinforced by research by Bayuk \& Altobello (2019), some of which explain the mechanics' elements on the indicators, such as points that provide an assessment at every stage of financial management. At the level will give a rating on procedural at the stage of implementation. In addition, the leaderboard will display the ranking as a simple comparison to classify the problem that is happening, and the badge gives a particular sign on the problem so that the given handling can be focused.

The pandemic period also resulted in a change in the economic order (Aramia Fahriyah, 2020). It is starting with fluctuating systems, reduced working hours, and most of the online sales process. The interviews conducted in this study explained that managing finances in times of pandemic cause jobs are also more complicated and fatigue because employees must adapt quickly. Therefore, gamification also overcomes fatigue by regulating feelings and providing stable emotions. This was also explained earlier in Hamari et al. (2014). In addition to the aesthetic element, gamification also presents challenges by providing a more expressive and discovery sensation in managing finances.

This study provides updates on financial management with more systematic stages and can be used because it is relevant and easy to practice. Proses are done with the support of 
each stage of gamification application starting from stages $1-6$. However, there are differences of views on Lawande et al., (2016) research because it is explained that gamification is only in the scope of human resources in policymaking and employee engagement implementation. In contrast, this research proves that gamification can also be implemented in financial management in the business context. Meanwhile, Prasad et al., (2020) research only explain the perception of employee engagement aimed at company management. On the other hand, the pandemic period not only impacts the company but also affects employees directly.

\section{Conclusion}

Gamification is used to facilitate the performance of human resources as actors and be applied to the scope of finance personally. Thus, gamification is used as a strategy in addressing financial management problems that result in stress experienced by employees. The update on this study offers financial gamification as a method of financial management by utilizing the gaming process. Gamification refers to behavior changes by developing emotions on the game model.

This study explains that the application of gamification can reduce stress by creating pleasant feelings, reducing boredom, overcoming fatigue, and providing an interesting experience in managing finances. The scarcity of pandemic problems also creates gamification by making players financially literate in financial management. In addition, the gamification element, namely mechanics, dynamics, and aesthetics, can assess each financial management and procedural ranking at the implementation stage. In addition, this study provides updates on financial management with more systematic stages and can be used because it is relevant and easy to practice.

This study is limited to financial scope issues only. Moreover, the pandemic period also makes it difficult for researchers to collect data due to health protocols and reduce the spread of covid-19. Nevertheless, this study can be developed more comprehensively by reviewing the broader issues. The implementation of gamification strategies can be aligned with some scopes, such as production and marketing in the business context or other aspects of the organization. The implication of this research provides solutions related to problems that occur in the pandemic in practice and brings gamification as a science and understanding in financial management in theoretical aspects. Further studies can certainly strengthen this study and can be a future study in the face of unexpected moments such as the current pandemic period.

\section{References}

Aramia Fahriyah, R. Y. (2020). KEUNGGULAN KOMPETITIF SPESIAL SEBAGAI

STRATEGI KEBERLANJUTAN UKM DI ERA NEW NORMAL. 07 no 2(1), 1-9. 
Arief Dwi Saputra, Alfina Rahmatia, M. (2021). How personal factors grow students ' interest in entrepreneurship. Jurnal Manajemen Dan Pemasaran Jasa, 14(1), 6176. https://doi.org/10.25105/jmpj.v14i1.8336

AYH Hilal, S. A. (2013). Using NVivo for data analysis in qualitative research. International interdisciplinary journal of education

Barata, G., Gama, S., Jorge, J., \& Gonçalves, D. (2017). Studying student differentiation in gamified education: A long-term study. Computers in Human Behavior, 71, 550-585. https://doi.org/10.1016/j.chb.2016.08.049

Bayuk, J., \& Altobello, S. A. (2019). Can gamification improve financial behavior? The moderating role of app expertise. International Journal of Bank Marketing, 37(4), 951-975. https://doi.org/10.1108/lJBM-04-2018-0086

Cardador, M. T., Northcraft, G. B., \& Whicker, J. (2017). A theory of work gamification: Something old, something new, something borrowed, something cool? Human Resource Management Review, 27(2), 353-365.

https://doi.org/10.1016/j.hrmr.2016.09.014

Denny, P. (2013). The effect of virtual achievements on student engagement. Conference on Human Factors in Computing Systems - Proceedings, 763-772. https://doi.org/10.1145/2470654.2470763

Deterding, S. (2011). Situated motivational affordances of game elements: A conceptual model. CHI 2011 Workshop “Gamification," 3-6. http://gamificationresearch.org/chi2011/papers

Dichev, C., \& Dicheva, D. (2017). Gamifying education: what is known, what is believed and what remains uncertain: a critical review. In International Journal of Educational Technology in Higher Education (Vol. 14, Issue 1). International Journal of Educational Technology in Higher Education. https://doi.org/10.1186/s41239-017-0042-5

Domínguez, A., Saenz-De-Navarrete, J., De-Marcos, L., Fernández-Sanz, L., Pagés, C., \& Martínez-Herráiz, J. J. (2013). Gamifying learning experiences: Practical implications and outcomes. Computers and Education, 63, 380-392. https://doi.org/10.1016/j.compedu.2012.12.020

Ërgle, D., \& Ludviga, I. (2018). Use of Gamification in Human Resource Management: Impact on Engagement and Satisfaction. https://doi.org/10.3846/bm.2018.45 Gollwitzer, P. M., \& Oettingen, G. (2012). Goal pursuit. In R. M. Ryan (Ed.), Oxford 
Library of Psychology. The Oxford handbook of human motivation (p. 208-231). Oxford University Press

Hamari, J., Koivisto, J., \& Sarsa, H. (2014). Does gamification work? - A literature review of empirical studies on gamification. Proceedings of the Annual Hawaii International Conference on System Sciences, 3025-3034.

https://doi.org/10.1109/HICSS.2014.377

Hunicke, R., Leblanc, M., \& Zubek, R. (2004). MDA: A formal approach to game design and game research. AAAI Workshop - Technical Report, WS-04-04, 1-5.

Kevin Werbach, D. H. (2012). For the Win: How Game Thinking Can Revolutionize Your Business (Business \&). Wharton School Press.

Lawande, N., Mohile, R., \& Datta, S. (2016). Gamification and employee engagement: theoretical review on the role of HR. 183-198.

Minister of Manpower. (2020). Badai Pasti Berlalu, Panggil Kembali Pekerja yang terPHK Nanti. https://www.kemnaker.go.id/news/detail/menaker-badai-pasti-berlalupanggil-kembali-pekerja-yang-ter-phk-nanti

Mora, A., Riera, D., González, C., \& Arnedo-Moreno, J. (2017). Gamification: a systematic review of design frameworks. Journal of Computing in Higher Education, 29(3), 516-548. https://doi.org/10.1007/s12528-017-9150-4

Nacke, L. E., \& Deterding, S. (2017). The maturing of gamification research. Computers in Human Behavior, 71, 450-454. https://doi.org/10.1016/j.chb.2016.11.062

Novi Puji Lestari. (2020). New Normal : Ekonomi Vs Kesehatan. Arsip Publikasi IImiah Biro Administrasi. research-report.umm.ac.id

Populix \& Teman Bumil. (2020). Dampak Pandemi Terhadap Kondisi Mental Keluarga.

Prasad, Rao, M. M., Manager, S., Stock, K., Limited, B., District, F., \& Hyderabad 500032, G. (2020). Can Gamification Intervention Improve Engagement, Performance Efficiency Of Workforce-A Case Study With Information Technology Sector. International Journal of Advanced Science and Technology, 29(3), 1355013558. http://sersc.org/journals/index.php/IJAST/article/view/31558

Robson, K., Plangger, K., Kietzmann, J. H., McCarthy, I., \& Pitt, L. (2015). Is it all a game? Understanding the principles of gamification. Business Horizons, 58(4), 411-420. https://doi.org/10.1016/j.bushor.2015.03.006

Robson, K., Plangger, K., Kietzmann, J. H., McCarthy, I., \& Pitt, L. (2016). Game on: Engaging customers and employees through gamification. Business Horizons, 
59(1), 29-36. https://doi.org/10.1016/j.bushor.2015.08.002

Ryan, R. M., Deci Unwersity, E. L., \& Rochestu, /. (2014). Overview of Self-

Determination Theory: An Organismic Dialectical Perspective. Handbok of SelfDetermination, 1-33.

http://www.elaborer.org/cours/A16/lectures/Ryan2004.pdf\%0Ahttp://selfdeterminati ontheory.org/theory/

Sailer, M., \& Homner, L. (2020). The Gamification of Learning: a Meta-analysis.

Educational Psychology Review, 32(1), 77-112. https://doi.org/10.1007/s10648019-09498-w

Saputra, A. D. \& R. A. (2021). Gamification Model as a Business Strategy for MSMEs in Indonesia. Journal of Accounting and Strategic Finance, 4(1), 91-107.

http://jasf.upnjatim.ac.id/index.php/jasf/article/view/162

Seaborn, K., \& Fels, D. I. (2015). Gamification in theory and action: A survey.

International Journal of Human Computer Studies, 74, 14-31.

https://doi.org/10.1016/j.jhcs.2014.09.006

Sholikhah, A. (2016). Statistik Deskriptif Dalam Penelitian Kualitatif. KOMUNIKA: Jurnal Dakwah Dan Komunikasi, 10(2), 342-362.

https://doi.org/10.24090/komunika.v10i2.953

Simpson, B. P., \& Jenkins, P. (2015). Gamification and human resources: An overview.

Brighton: Brighton Business School., 1-6.

Sitorus, M. B. (2016). Studi Literatur Mengenai Gamifikasi untuk Menarik dan

Memotivasi: Penggunaan Gamifikasi saat ini dan Kedepan. Studi Literatur, 1-10. 